alleviating circumstance which ought to reduce the offence to manslaughter'. This is only a minor modification of the Butler Committee's $s^{4}$ own suggested rewording. For both, 'mental disorder' as defined in the Mental Health Act (1959) should replace 'abnormality of mind' in the Act, despite the fact that the Homicide Act preceded the 1959 Act and the 1959 Act was not designed for this purpose. Professor Bluglass, whilst agreeing that the language of the Act is imprecise, took a more sanguine and pragmatic view-as was his remit. These are difficult issues with which the courts need our help; however, we might like to see the law changed, the immediate task for the psychiatrist is to decide what are the intellectual and ethical boundaries of forensic psychiatry and how he can best perform the present tasks asked of him. He quoted from Stones (Professor of Law and Psychiatry, Harvard University), who has taken on the mantle of inquisitor and conscience, but also teacher, of forensic psychiatry in these matters.

Dr J. Hamilton (Medical Director, Broadmoor Hospital) widened the discussion by examining the grey area between complete lack of responsibility (the Insanity Defence) and diminished responsibility, the other side, as it were, of the debate. He believed that one could not approach reformulation of the Homicide Act without also considering the Butler Committee proposals for reforming the McNaughton Rules and disposals under the Criminal Procedure (Insanity) Act of 1964. Since he held the view that 'everyone is agreed that the McNaughton Rules are most unsatisfactory and are based on an outdated concept of mental disorder', he clashed with what Dr Kenny described as his own antediluvian views. Dr Kenny would scrap the Homicide Act and not replace it, and, further idiosyncratically, argued for the adequacy of the McNaughton rules in their original form: his views have been set out elsewhere. ${ }^{6}$

Dr Hamilton cited clinical examples of the confusion presently surrounding the legal status of automatism and epilepsy, particularly since the ruling of R. v Sullivan (1983). One of his examples drew out the possible conflict of legislation that the Mental Health Act (1983) and new powers of Mental Health Review Tribunals pose to recent insanity rulings in regard to epilepsy and the categories of insane and non-insane automatism. He asked for debate of these specific and topical issues in addition to a general review of insanity legislation.

\section{Conclusion}

It will no doubt be agreed-particularly, perhaps, after this brief and superficial gloss- that these issues are conceptually complex and often elusive. They are also emotive and contentious, touching as they do on questions of our most fundamental human values. Frequently they have only a tangential relation to psychiatric theory.

Whitlock ${ }^{7}$ has drawn attention, as have others, to the different language usage and philosophy of ideas which layman, psychiatrist, jurist and philosopher bring to these arguments, of which there was ample evidence at this meeting - although never totally irreconcilably. He also comments that 'there is no room for extremes of opinion or over-riding rights in the controversy over criminal responsibility'.

There is no ideal model available-only approximation. Peremptory changes in the insanity law elsewhere, e.g. in certain States of the USA following the Hinckley trial, have produced more rather than less anomaly, and in some cases these changes have had to be revoked (Caplan ${ }^{8}$ ).

Even so, a debate on the now ten-year-old Butler Committee proposals, those of the CLRC and those of many individual critics would seem to be overdue, although it is doubtful how much will be achieved where there appears to be a lack of political and judicial will.

My own view is that ideas and policies change but do not always progress, and that this subject has more of a cyclical history than many. All proposals for change made at this Conference, for example, would exclude provision for any special pleading for states of extreme emotion-which can qualify within the present Homicide Act. It was salutary to hear Dr Higgins cite the judge's summing up in $R$. $v$ Walker (1784) - the case of a pauper who had murdered his wife: 'Rage, which is the effect of distemper', he said 'is brought upon them by the Act of God, and not by themselves, and they are not answerable for what they do in those moments'. Walker was acquitted. Would we really want our 'reforms' to exclude the possibility of such a humane verdict, in whatever exceptional circumstances, two hundred years on?

\section{REFERENCES}

IWALKER, N. (1968) Crime and Insanity in England. Edinburgh University Press.

2DELL, S. (1984) Murder into Manslaughter. Maudsley Monograph, No 27. Oxford University Press.

3Criminal Law Revision Committee: Home Office (1980) Offences Against the Person (14th Report). Cmnd 7844. London: HMSO.

4Home OfFice; DHSS (1975) Report of the Committee on Mentally Abnormal Offenders (The Butler Report). Cmnd 6244. London: HMSO.

SSTONE, A. (1984) The ethics of forensic psychiatry: A view from the Ivory Tower. In The Law, Psychiatry and Morality. American Psychiatric Press.

6Kenny, A. (1984) The psychiatric expert in Court. Psychological Medicine, 14, 291-302.

TWrrtock, F. (1963) Criminal Responsibility and Mental Illness. London: Butterworths.

${ }^{8}$ Caplan, L. (1984) Annals of law: The insanity defense. New Yorker, July, pp. 45-78.

\title{
Christmas Cards
}

A pictorial reproduction of No. 17 Belgrave Square, from an original watercolour by $\mathrm{Dr} \mathrm{J}$. Horder, is available from the College at 20p each (plus postage of 53p per dozen). A second design is also available-the College Coat of Arms, die stamped in colour, priced 35p each (plus postage of 31p per dozen). 